International Journal of Heritage, Tourism and Hospitality Vol. (11), No. (3/2)

Special issue on papers of the $10^{\text {th }}$ ICTH (2017) organized by Faculty of Tourism and Hotels, Fayoum University

\title{
Tree Goddess Scenes in the New Kingdom Private Tombs at Thebes
}

Taher Abdelhamid

Faculty of Tourism \& Hotels, Fayoum University

\begin{abstract}
Tree cults in the historical period began with purely local cults which at an early time became associated with nonlocal deities as their forms or attributes. Most plants other than trees played an important part only in magic, medicine, and folklore.

The ancient Egyptian glorified the sycamore $n h t$ and they adopted it as the mansion of goddess. Furthermore, they adore the broad-leafed persea $i \breve{s} d$ tree. The date palm, $b n r^{c}$ - the word means "sweet"-a garden tree common in the dynastic period and in modern Egypt. In addition, the acacia (šnd), a tree which has always been very common. All previous trees were the most important trees in ancient Egyptian dogma. Private tombs of the New Kingdom were shown these two trees on their walls.

This paper aims to investigate the tree goddess scenes in Theban necropolis during the New Kingdom. It will be make analysis to tombs' scenes to deduct the following points: the different positions of the deceased, the place of these scenes, the shapes of goddess, the kinds of gifts which the goddess presents to the dead man, the goddesses which connected to the tree goddess and the similar and different countenances between each cemetery in Theban necropolis concerning these scenes. This paper employs a descriptive and analytical methodology. The study explains the most preserved scenes but in its analysis makes an inventory to all scenes.

Through studying the scenes of the tree goddess in the New Kingdom private tombs at Thebes, this study concludes that there are fifty eight scenes were depicted. The tree goddess takes different shapes and there were not a specific place for it in the tomb.
\end{abstract}

Keywords: Tree Goddess, Theban Necropolis, New Kingdom, Private tombs.

\section{Introduction}

The sacred trees in Ancient and modern Egypt are often supposed to possess curative properties and their leaves are believed to be a cure for sore eyes and various other ills. Several species of these trees were considered sacred in Egyptian mythology. Votive offering may be seen hanging from the trees, but this is more usual when there is no tomb, for when such a building exists the offerings are hung within it. Very many of the trees have large nails cling into their trunks, recording prayers offered by worshippers (Maspero, 1910; Buhl, 1947, Khoshaim, 1998).

The sycamore was a large and impressive tree. It has a dense crown. This characteristics feature makes the Egyptian to regard it as the tree deity. In addition, the broad-leafed persea $i \check{s} d$ tree and palm-tree were between the preferred Egyptian tree which drawn on the walls of tombs and temples (Hart, 1986; Germer, 2001).

Although there are many studies dealing with the tree cult and the sycamore tree but none of them address tree Goddess scenes in New Kingdom private tombs as a separate topic.

"Picture analysis" is used as a methodology to be relevant to the historical approach. It is an appropriate method for the topic of this research. According to the number of the scenes of tree goddess in New Kingdom private tombs, this methodology helps the researcher to select some scenes which achieve the aims of this paper. Furthermore, he chooses the different scenes not the similar ones. 


\section{The tree goddess in the religious texts}

The conception of personified trees is found as early as the Old Kingdom, in texts as well as iconography (Davies, 1900). In Pyramid texts, Spell 689: "The sycamore will be your food and its fruit too" (Buhl, 1947, Faulkner, 1969). It was mentioned again in spell 916a-b: "The high places bring him to the places of Seth and to that high sycamore of the eastern sky when it has bent down (its branches) on which the gods are" (Buhl, 1947; Faulkner, 1969). Moreover, spell 1485a describes one concept of such a supernatural tree: "Hail thou Sycamore who protects the god under which the gods of the underworld are standing" (Faulkner, 1969).

The Pyramid Texts only mention the sycamore tree without connecting it with a particular deity (Buhl, 1947).

In the Middle Kingdom, the new redaction of the funerary literature, the Coffin Texts, does not include any descriptions of personified trees, but presents another motif concerning the same meaning of the tree goddess. In (Coffin Text, III, 124d-j [P. 199]; $1 \mathrm{~d}-\mathrm{g}$ [P. 164]; 51f-g [P. 173]; $86 \mathrm{f} ; 87 \mathrm{c}$ [P. 186]), "Where is it granted for you say they who under the branches of the sycamores, I desire it, together with the musicians of Hathor" (Faulkner, 1977, 1978; Eschweiler, 1994; Billing, 2004).

The Book of the dead, chapters 52-63 are intended to ensure air and water to the deceased and as a symbol of fresh air or wind, the deceased is often represented with a great sail. The deceased prays to the god Turn for a breath of sweet air to his nostrils, and to the goddess Nut for a drink of pure water "O, Sycamore of Nut," he says, "give me the air and the water that is there" (Tirand, 1910; Eschweiler, 1994; Budge, 2008).

In chapter (52 A), Turin Papyrus, (British Museum, 10477, sheet 11), "The horned gods will ask me where would you. (I) want to eat and I answered under the sycamore tree" (Budge, 1910; Barguet, 1967; Ali, 2001). Chapters 59B and 189 contain the same meaning of chapter 52A.

The goddess is depicted in chapter 59(Any Papyrus) as a woman emerging from the trunk of the tree while presenting food and water to the deceased (Fig. 1) (Budge, 1910; Keel, 1992; Ali, 2001). Furthermore, chapter 63A ( $N w$ Papyrus, British Museum, 10477, sheet 7) showed a tree growing on the edge of a lack while a human hand spoiled water to the dead man who is receiving it on a flask (Fig. 2) (Hornung, 1990, Taylor, 2010; Quirke, 2013). All the previous texts were the way to study the New Kingdom private tombs' scenes.

\section{Displaying of Scenes}

Tree Goddess was depicted on tombs walls, stele, papyri, coffins (PM, 1927; Abdul-Qader, 1966; Ali, 2001; Billing, 2004). This paper focuses only on tombs' scenes. There are many representations of this goddess in a form of a tree bearing a tray with bread or fruit and a vase of water. The deceased often receives the water in the hollow of his hands and quenches his thirst (Billing, 2004).

During the eighteenth dynasty, the earliest representation of Tree goddess was shown during the reign of Thutmosis III. The study explains the most preserved scene in this dynasty as follows:

Doc. 1: the earliest representation of Tree goddess was shown in the tomb of Puemere (TT 39) at El-Khokha (reign of Thutmosis III) (Fig. 3). The scene was depicted on the top of the two outer jamb of the shrine. The goddess is represented as a woman with a tree upon her head. She is holding a mat full of offering and turning forward to the door of the shrine (Davies, 1917; AbdulQader, 1966).

Doc. 2: In the reign of Amenhotep II, the tomb of Kenamun (TT 93) at Shaikh Abd El-Qurna (Fig. 4), the Goddess was shown under the sycamore tree while the tomb owner site on the other 
side in front of an offering table. Although the scene is destroyed, Abdul-Qader (1966) suggested that the sycamore tree is grown in a garden which has a lake (Abdul-Qader, 1966, Davies, 1973). The text which accompanied the scene is read:

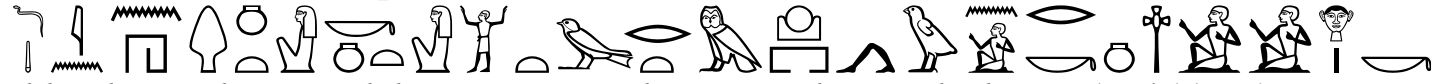

dd mdw in nht nwt ink k3t nwt wrt $m$ 3ht iw.n.i r.k inw.i hr.k Word said by the sycamore Nut: I am Nut, high and great in the horizon, I came to you bringing gifts (Davies, 1930, Buhl, 1947).

Doc. 3: The tomb of Sennufer (TT 96 B) in the reign of Amenhotep II at Shaikh Abd El-Qurna (Fig. 5), the tomb owner and his wife were depicted sitting on two chairs while a tree was placed opposite them on a table. A human figure is forms the trunk of the tree (Wilkinson, 1847; Viery, 1898; Eggebrechet, 1986; Calmettes, 2007). The text is read:

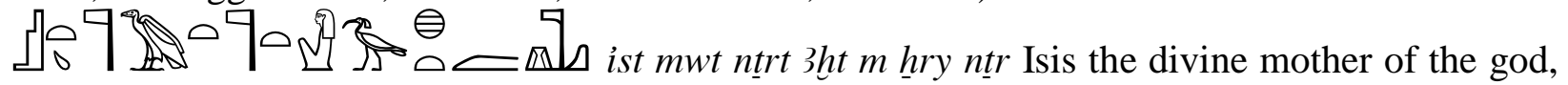
the spirit in the necropolis (Helck, 1956; Cumming, 1984).

Doc. 4: The goddess is depicted on the west wall of the tomb of Nakht (TT 52) at Shaikh Abd El-Qurna (reign of Thutmosis IV) (Fig. 6). She stands on either side of a huge offering table. In one hand she is provided with a tray of bread, onion, beer, grapes, while the other holds a long papyrus stem (Davies, 1917; Wildung, 19978; Kammp, 1996; Shedid and Seidel, 1996; Hartwig, 2004).

Doc. 5: In the tomb of Sobekhotep (TT63) in the same reign and cemetery (Fig. 7), the goddess is represented in a new form. She is formed the trunk of a tree. It was depicted twice on the left and right of a lake. The tomb owner and his wife were sitting on two chairs under another larger tree, the tree presents to them libation, bread and figs. Biki (1993) pointed that this scene refers to the paradise of the Egyptian. He suggested that she was Isis in the form of the persa tree $i \check{s} d$ (Speigel, 1956; Abdul-Qader, 1966; Biki, 1993). The text is read:

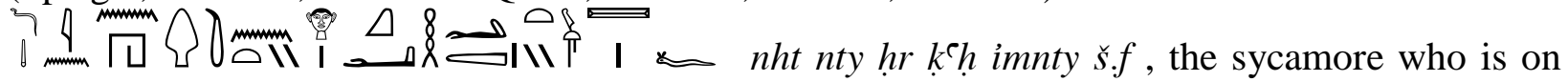
the western corner of his lake (Speigel, 1956). The same text is repeated except the corner was iAbty eastern.

Doc. 6: On the right of the pillared hall of the tomb of Nefehotep (TT 49, probably reign of Ay) at El-Khokha (Fig. 8), the goddess was shown a little figure growing from the trunk of the tree. The couples were shown standing while receiving bread and water from her hands (PM, 1927; Davies, 1933; Buhl, 1947). The accompanied text is read:

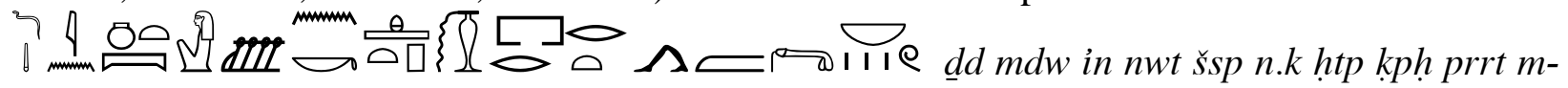
$b 3 h n b w$ Word said by Nut "receive the offering and the purified water in front of the lord...." (Davies, 1928; Ali, 2001; Ghaly, 2017).

Doc. 7: The passage of the Neferhotep tomb (TT 50, time of Horemheb) at Shaikh Abd El-Qurna (Fig. 9), the tree goddess is shown. Although the scene is destroyed it is worth to display its details. The goddess here appears from the tree while holding food and the jar of waters. She is shown wearing a long hair wig and a diadem above it. Above all her name is depicted above her head (with $n w$ jar and the emblem of the sky) (PM, 1927; Hari, 1985).

The deceased is shown, in front of the goddess, without his wife while receiving gifts from the goddess (Fig. 10). This scene occurred on North Wall of the hall in the tomb of Roy (TT 255, time of Horemheb) at Dra Abu El-Naga. The goddess is wearing a short hair wig (PM, 1927; Baud, and Driton, 1928; Abd El-Mohsen, 2013). The inscribed text is read: hr nbt imntt Hathor the lady of the western (PM, 1927, Baud, and Driton, 1928; Ghaly, 2017). 
During the nineteenth dynasty, the scenes of the tree goddess became popular. As a result of that the study explains the well-preserved scenes as follows:

Doc. 1: The tomb of Amunmose (TT 19, rein of Ramses I to Sety I?) at Dra Abu El-Naga (Fig. 11) shows the goddess emerging from the tree. She is shown behind the couples. They are sitting facing right on a chair. A woman is shown emerging from the tree while distributing food and drink to the ba-birds of the deceased and his wife under the tree (Wreszinski, 1923; Foucart, 1932; Buhl, 1947).

Doc. 2: Tomb of Amenemope (TT41, time of Ramses I to Sety I?) at Shaikh Abd El-Qurna (Fig. 12) has a good scene on the west wall of the hall in which the tree growing from a lack. The goddess appears from the tree and spoils water to the couples. They were kneeling and drinking water by their hands. The two ba-birds were shown on high stool, one in front of the man and the other behind his wife (Assmann, 1983, 1984, 1991; Kammp, 1996).

Doc. 3: In the tomb of Userhet (TT 51, period of Sety I) at Shaikh Abd El-Qurna (Fig. 13), the scene is depicted on the west wall of the hall. It shows the deceased sitting with his wife and mother under the shade of a big sycamore. In the background is the tree goddess is shown as a woman with a tree on her head. The two bas were shown twice one above the couple and the other in front of the tree goddess while drinking her libations (Davies;, 1927; Buhl, 1947; Ali, 2001, Weeks, 2005).

Doc. 4: During the reign of Ramses II, the tomb of Neferhotep (TT 6) at Deir el-Medina (Fig. 14), the goddess is represented as a winged woman while pouring water from to jars to the deceased (Foucart, 1924; Wild, 1979, Valbelle, 1985, Wilkinson, 1992).

Doc. 5: In Panehsy tomb (TT 16, time of Ramses II) at Dra Abu El-Naga (Fig. 15), the dead man is shown kneeling under the tree on the right of the entrance of the hall. He is drinking water with his ba which pouring from the tree. The goddess is shown with all sign of ornament. We can see a star on her head, the emblem of the sky goddess Nut (Baud and Driton, 1932; Speigel, 1956; Saleh, 1984). The text is read: (Ali, 2001). This text repeated in TT 19, 106, 133, and 138 (Abdul-Qader, 1966).

Doc. 6: In the tomb of Tjanufer at Dra Abu El-Naga (TT 158, probably time of Ramses II) (Fig. 16), there is a relief of the tree goddess in the left thickness of the hall. The owner of the tomb is seated at the right before him is a ka-like table on a standard. A leafless sycamore tree is shown behind the table bearing a few figs. The tree goddess is shown standing among the main branches of the tree. She is represented in human form with only the feet hidden. she grasps in one hand a small basket with figs from the tree, while the other pours several streams of water from a vase for a ba-bird with human head on the ground under the offering table. On the left of the tree, the deceased is shown wearing sandal. He is kneeling down with his back to the tree to drink water from T-shaped lack surrounded by palm-tree. (Buhl, 1947; Seele, 1959; AbdulQader, 1966; Ali, 2001)

Doc. 7: In the tomb of Nakhtamun (TT 341, reign of Ramses II) at Shaikh Abd El-Qurna (Fig. 17), The goddess is shown wearing a long hair wig and a tight fitting dress. She presents figs to the deceased and his wife. She grasps on the other hand a sistrum. The couples seated on one chair with all signs of dignity. They receive figs and water by their hands. The tree here used as background of the scene (PM, 1927; Davies, 1948; Bleeker, 1973; Murray, 2000; El-Shahawy, 2010, Vandersleyen, 2012).

Doc. 8: A well-preserved painting of special interest for the tree goddess is shown in the tomb of Sennedjem (TT 1, during the $19^{\text {th }}$ dynasty) at Deir el-Medina (Fig. 18). The scene reveals the deceased and his wife kneeling at their tomb. In front of them the goddess is shown standing in a 
sycamore. The trunk of the tree hides her legs and the lower part of her body. The tree is laden with fruit and well covered with thick foliage. The goddess offers the usual water jar and tray of bread to Sennedjem and his wife. They are depicted in kneeling position and extend their hands to receive the gifts (Buhl, 1947; Abdel Ghaffar, 1994; Abd El-Mohsen, 2013).

Doc. 9: on the North Wall of the hall of the Tomb of Hui (TT 54, during the $19^{\text {th }}$ dynasty) at Shaikh Abd El-Qurna (Fig. 19). The deceased is shown standing beside his wife while a lady emerge from the tree and pouring water to them. The lady is holding a tray of food with her left hand. The couples is depicted with their best handsome. The ba-bird and a child are represented receiving water with their hand beside the hands of the deceased (Ploz, 1928).

During the twentieth dynasty, the representation of the tree goddess became rare. There were preserved scenes as follows:

Doc. 1: The tomb of inherkau (TT 299, reigns of Ramses III to IV) at) at Deir el-Medina (Fig. 20) has a marvelous scene. The tree goddess is depicted as a winged woman who emerging from a lack. She is shedding steams of water to the deceased who is in a squatting position (Bruyere, 1928; Abd El-Wahab, 1959; Shedid, 1994; Haring, 2007). In this tomb the text is read: 1 $d d m d w$ in nwt wrt Words said by the great Nut (Bruyere, 1928, Ali, 2001).

Doc. 2: Tomb of Amunemounet at Qurnet Murai (TT 277, Ramesside period), (Fig. 21), shows the couples seated on one chair. They raised their hand to receive gifts from the goddess who emerging from the tree. The goddess here wears a long hair wig above it the sun disc between two horns (the emblem of goddess Hathor) (Foucart, 1918; Vandier d'Abbadie, 1954, Saleh, 1984; Robin, 1994; Hofmann, 2004; El-Shahawy, 2010).

Doc. 3: Tomb of haty'ay at Shaikh Abd El-Qurna (TT 324, Ramesside period), (Fig. 22), contains a scene of the tree on the North Wall of the hall (right of the entrance). The goddess emerging from the top of a big tree while she is pouring streams of water to the couples with one hand and food with the other. They were shown standing while the husband wearing a sandal but his wife not. The tree goddess is wearing a long hair wig. The two bas of the couples were standing on chapel and receiving water too. The tree is growing from a lack beside a house. The lack was full of fishes and lotus. In the lack was a bark in which the couples come to this place (PM, 1927; Davies, 1948).

\section{Discussion and Results}

1- Number of scenes: The total numbers of scenes directly related to the tree goddess in New Kingdom private tombs are fifty eight scenes. The following table shows the number of these scenes in each cemetery:

Table 1: the number of tree goddess scenes.

\begin{tabular}{|l|l|l|l|l|l|l|l|}
\hline Cemetery & $\begin{array}{l}\text { Dier El- } \\
\text { Medina }\end{array}$ & $\begin{array}{l}\text { Shaikh Abd } \\
\text { El-Qurna }\end{array}$ & $\begin{array}{l}\text { Dra Abu } \\
\text { El- Naga }\end{array}$ & Khokha & Asassif & $\begin{array}{l}\text { Qurnet } \\
\text { Murai }\end{array}$ & Total \\
\hline No. & 19 & 17 & 10 & 5 & 3 & 3 & 58 \\
\hline
\end{tabular}

These numbers became clearer in the following chart: 
Chart 1: The number of tree goddess

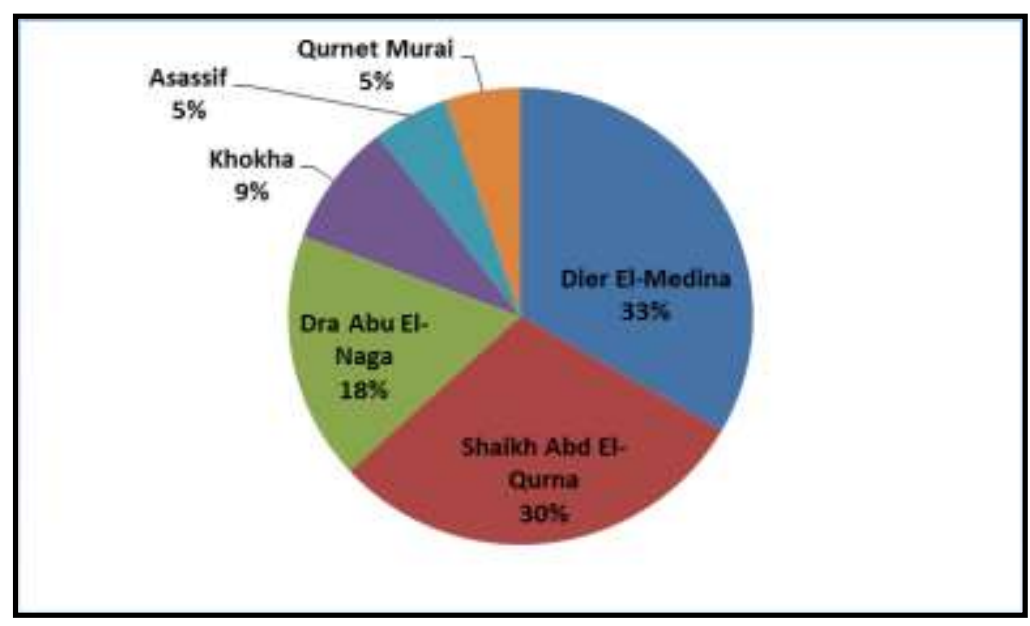

The previous table and chart shows the number of tree goddess scenes. The Cemetery of Dier ElMedina had the large number. This is as result for the whole number of tombs which dated to the Ramesside period. Evidently, these scenes became popular in this period. It had 19 scenes (33\%) while Shaikh Abd El-Qurna had 30\%, Dra Abu 18\%, El- Naga, Khokha 9\%, and Asassif and Qurnet Murai had the same percentage 5\% for each.

\section{2- The place of the tree goddess scenes}

Throughout the observation, which one tool of "Picture analysis" methodology, the research collected the places of scenes in each cemetery in the following tables:

\section{A. Khokha}

Table 2: Khokha cemetery scenes

\begin{tabular}{|l|l|l|l|l|l|l|l|l|l|}
\hline TT & \multicolumn{1}{|c|}{ Reign } & Hall & Inner room & shrine & North & South & East & West & observation \\
\hline 39 & Thutmosis III & & & $\mathrm{X}$ & & & & & right of \\
\hline 176 & Amenhotep II & $\mathrm{X}$ & & & & & $\mathrm{X}$ & & right of \\
\hline 49 & Prob. Aye & $\mathrm{X}$ & & & $\mathrm{X}$ & & & & right of \\
\hline 178 & Ramses II & $\mathrm{X}$ & $\mathrm{X}$ & & & & & $\mathrm{X}$ & right of \\
\hline 276 & Ramses II & $\mathrm{X}$ & & & & & $\mathrm{X}$ & & \\
\hline
\end{tabular}

The previous table shows that tree goddess scenes at Khokha were depicted on the hall, inner room and shrine. Furthermore, the right of the entrance was the most preferred position of it.

\section{B. Shaikh Abd El-Qurna}

Table 3: Shaikh Abd El-Qurna cemetery scenes

\begin{tabular}{|c|c|c|c|c|c|c|c|c|c|c|c|}
\hline TT & 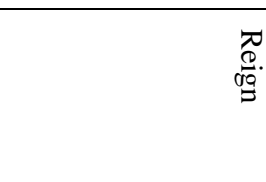 & $\stackrel{\varrho}{\Xi}$ & 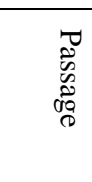 & $\stackrel{\mathbb{T}}{\stackrel{I}{=}}$ & $\begin{array}{l}z \\
\frac{Z}{\sigma} \\
\frac{\sigma}{\sigma}\end{array}$ & 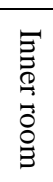 & $\begin{array}{l}\text { Zz } \\
\stackrel{g}{\Xi}\end{array}$ & $\begin{array}{l}\tilde{2} \\
\vdots \\
\Xi \\
\xi\end{array}$ & 晃 & 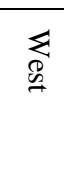 & $\begin{array}{l}\stackrel{8}{0} \\
0 \\
\mathbb{Z} \\
\tilde{0} \\
\stackrel{0}{0}\end{array}$ \\
\hline 93 & Amenhotep II & & & $X$ & & & $X$ & & & & \\
\hline 96 & Amenhotep II & & & $\mathrm{X}$ & & & & & & $X$ & pillar \\
\hline 52 & Thutmosisis IV? & & & $X$ & & & & & & $\mathrm{X}$ & \\
\hline 63 & Thutmosisis IV & & $\mathrm{X}$ & & & & $\mathrm{X}$ & & & & \\
\hline
\end{tabular}


International Journal of Heritage, Tourism and Hospitality Vol. (11), No. (3/2)

Special issue on papers of the $10^{\text {th }}$ ICTH (2017) organized by Faculty of Tourism and Hotels, Fayoum University

\begin{tabular}{|c|c|c|c|c|c|c|c|c|c|c|c|}
\hline 50 & Aye? & & $\mathrm{X}$ & & & & & & & & \\
\hline 41 & Ramses I to Set I & $\mathrm{X}$ & & $\mathrm{X}$ & & & & & & $\mathrm{X}$ & \\
\hline 51 & Sety I & & & $\mathrm{X}$ & & & & & & $\mathrm{X}$ & Left of entrance \\
\hline 106 & Sety I to Ramses II & & & $X$ & & & & & $\mathrm{X}$ & & right of entrance \\
\hline 23 & Merenptah & $\mathrm{X}$ & & $X$ & & & $\mathrm{X}$ & & & $\mathrm{X}$ & \\
\hline 133 & Ramses II & & & $\mathrm{X}$ & & & & & $\mathrm{X}$ & & \\
\hline 137 & Ramses II & & $\mathrm{X}$ & & & & & $X$ & & & Left of entrance \\
\hline 138 & Ramses II & & & $X$ & & & & & $X$ & & \\
\hline 341 & Ramses II & & & & & $X$ & $\mathrm{X}$ & & & & \\
\hline 135 & 19 dynasty & & & $X$ & & & & $\mathrm{X}$ & & & \\
\hline 54 & 19 dynasty & & & & $X$ & & $\mathrm{X}$ & & & & \\
\hline 324 & Ramesside & & & $\mathrm{X}$ & & & $\mathrm{X}$ & & & & right of entrance \\
\hline 58 & 20 dynasty & & & & & $\mathrm{X}$ & & $\mathrm{X}$ & & & \\
\hline
\end{tabular}

The previous table shows that the tree goddess scenes were shown at Shaikh Abd El-Qurna cemetery on all parts of the tomb except the burial chamber. The hall of the tomb was the preferred place for these scenes. We can noticed that no particular wall for the representation of this goddess.

\section{Dra Abu El-Naga}

Table 4: Dra Abu El-Naga cemetery scenes

\begin{tabular}{|l|l|l|l|l|l|l|l|l|l|}
\hline TT & Reign & Passage & Hall & Inner & North & South & East & West & observation \\
\hline 333 & Amenhotep III? & & & X & & & & X & \\
\hline 255 & Horemheb ? & & X & & X & & & & \\
\hline 19 & Ramses I to Sety I & & X & & X & & & & \\
\hline 16 & Ramses II & & X & & X & & & & right of entrance \\
\hline 158 & Prob. Ramses II & X & X & & & & & X & Left of entrance \\
\hline 306 & 19 dynasty & & X & & & X & & & right of entrance \\
\hline 284 & Ramesside & & X & & & & X & & right of entrance \\
\hline 285 & Ramesside & & X & & & X & & & right of entrance \\
\hline 286 & Ramesside & & X & & & X & & & right of entrance \\
\hline 379 & Ramesside & & X & & & & X & & \\
\hline
\end{tabular}

Dra Abu El-Naga cemetery contains ten scenes of tree goddess. Eight of them were shown in the hall, so it was the best place for it. Tree Goddess was depicted on all the walls but the right of entrance was the preferred place, specially the right side.

\section{Dier El-Medina}

Table 5: Dier El-Medina cemetery scenes

\begin{tabular}{|l|l|l|l|l|l|l|l|l|l|l|}
\hline TT & Reign & Chapel & Burial chamber & shrine & North & South & East & West & ceiling & entrance \\
\hline 292 & Set I to Ramses II & & X & X & & & & & X & \\
\hline 2 & Ramses II & & & & & & & & & \\
\hline 4 & Ramses II & $\mathrm{X}$ & & & & X & & & & \\
\hline 6 & Ramses II & & & X & & & & & X & \\
\hline 7 & Ramses II & $\mathrm{X}$ & & & & & & & & X \\
\hline 9 & Ramses II & $\mathrm{X}$ & & & & & $\mathrm{X}$ & & & \\
\hline 216 & Ramses II to Sety II & & $\mathrm{X}$ & & & & & & $\mathrm{X}$ & \\
\hline
\end{tabular}


International Journal of Heritage, Tourism and Hospitality Vol. (11), No. (3/2)

Special issue on papers of the $10^{\text {th }}$ ICTH (2017) organized by Faculty of Tourism and Hotels, Fayoum University

\begin{tabular}{|l|l|l|l|l|l|l|l|l|l|l|}
\hline 1 & 19 dynasty & & X & & & & & & X & \\
\hline 219 & 19 dynasty & X & & & & & X & & & \\
\hline 335 & 19 dynasty & & X & & X & & & & & \\
\hline 356 & 19 dynasty & & X & & & & X & & & \\
\hline 211 & 19 dynasty & & X & & & & & & X & \\
\hline 213 & 19 dynasty & X & & & & & & & & X \\
\hline 299 & Ramses III to IV & & X & & & & & & X & \\
\hline 3 & Ramesside & & X & & & & & X & & \\
\hline 5 & Ramesside & & X & & & & & & X & \\
\hline 218 & Ramesside & X & & & X & & & & & \\
\hline 219 & Ramesside & X & X & & & X & & & & \\
\hline 290 & Ramesside & & X & & & & & & X & \\
\hline
\end{tabular}

The scenes of Dier El-Medina cemetery were depicted on the chapel, burial chamber and shrine. On the other hand, the inner part of the tomb contains the most number of these scenes. In fact, this is the reason for the order of tombs' owners who wants to hide these scenes. In any case, the workers of the necropolis of Deir El-Medina depict some scenes which attributed for the kings and high officials in their tombs such as the Osiris court.

Tree goddess Scenes were depicted on all the walls of the tomb but the ceiling was the best place for it as she is Nut, the sky goddess.

\section{E. Qurnet Murai}

Table 6: Qurnet Murai cemetery scenes

\begin{tabular}{|l|l|l|l|l|l|l|l|}
\hline TT & Reign & Hall & North & South & East & West & observation \\
\hline 273 & Ramesside & X & & & & X & left of entrance \\
\hline 277 & Ramesside & X & X & & & & \\
\hline 278 & Ramesside & X & & & X & & \\
\hline
\end{tabular}

Form the previous table; we can note that the hall of the tomb at Qurnet Murai was the place of tree goddess' scenes. She was shown in all walls except the South Wall.

F. Asassif

Table 7: Asassif cemetery scenes

\begin{tabular}{|l|l|l|l|l|l|l|l|l|l|}
\hline TT & Reign & Hall & Inner & North & South & East & West & ceiling & observation \\
\hline 387 & Ramses & $\mathrm{X}$ & & $\mathrm{X}$ & & & & & left of entrance \\
\hline 409 & Ramses & & $\mathrm{X}$ & & $\mathrm{X}$ & & & & left of entrance \\
\hline
\end{tabular}

Asassif cemetery looks like Khokha. The entrance of the hall was the best place in which tree goddess was shown.

To summing up, we can say that there wasn't a specific place for the scenes of the tree goddess in Theban tombs. By the way, we have noted that the hall was the preferred place for these scenes.

\section{3- The different positions of the deceased and his wife}

The deceased is shown with his wife whereas is depicted without his wife in TT 16, 273, 286 (but 273, 16 another scenes in wife). Sometimes, they were standing TT 49, 52, 324 or kneeling $158,286,41$. Moreover, they were sitting on two chairs in TT 63 or on one beside each other TT $19,49,51,277$. On one scenes in TT 96B, the husband is shown sitting on chair while his wife kneeling on the ground and holding his leg. They appeared with sandals in TT 158, 324 or without 79,16 , and 341 . 
In two tombs the deceased is shown (beside his wife) with his children in TT 54 and with his mother TT 51. TT 96B had un-common scene in which the deceased is sitting on a high chair while his wife sitting on low one.

The ba of the deceased in a form of a bird with two hands and human head drink with their two hand appeared from the reign of Horemheb. One ba appeared with the dead man (TT 16) then became two for the couples. They were shown in front of the couples (TT 277, 324) or behind them (TT 19). Sometimes the two bas were shown twice one above the couple the other in front of the tree goddess while drinking her libations (TT 51). In two uncommon scenes, the ba-birds were represented one behind the man and the other behind his wife (TT 41), the second scene is shown in the other side of the tree (TT 158).

\section{4- The shapes of the tree goddess}

Table 8: Shapes of the tree goddess

\begin{tabular}{|l|l|l|l|l|l|}
\hline \multicolumn{3}{|c|}{ Woman } & \multicolumn{3}{c|}{ Woman emerging from a tree } \\
\hline Tree on head & Under tree & Woman without tree & From trunk & branches & Arms only \\
\hline 3 & 2 & 1 & 15 & 24 & 13 \\
\hline
\end{tabular}

The previous table shows an inventory for the different shapes of the tree goddess. It was represented as a woman with tree on head, udder tree, and woman only without tree. Furthermore, it was depicted as a lady emerging from the trunk or branches of a tree and also sometimes her arms appeared only.

Sometimes the tree, in which the tree appears, was grown from a lake 51, 16, and 106. The lack in TT 324 was full of fishes and lotus. In addition, the tree serve as a background in TT 51 was under the shade in which the couple sit.

The earliest shape of the goddess was depicted as a maid with a tree growing from her head. She is pouring a libation with one hand and giving food with the other. This shape occurred in eighteenth dynasty (TT 39, 52). Moreover, in TT 93 the goddess wasn't form part of sycamore tree but she is shown as a lady under the tree. TT 96B the tree was placed opposite the deceased and his wife on a table.

From the end of eighteenth dynasty onward the goddess is represented as a lady emerging for the trunk of a big tree as in TT 19, 41, and 16. Furthermore, she was depicted as a winged woman in two scenes only in TT 6, and 299.

Usually the woman wears a long hair. On the other hand, she was shown with a short hair in TT 255. The legs of the goddess were hidden in the trunk of the tree except in uncommon scene in

TT 1 the trunk was magnified her body.

\section{5- Names of the goddess}

Table 8: Names of the goddess

\begin{tabular}{|l|l|l|}
\hline \multicolumn{2}{|c|}{ The name appeared } & \multicolumn{1}{c|}{ Without names } \\
\hline \multicolumn{1}{|c|}{ Texts } & \multicolumn{1}{|c|}{ Scenes } & \\
\hline 8 Nut & 1 Nut & 49 \\
\hline Isis & & \\
\hline Hathor & 2 Hathor & 49 \\
\hline Total & 13 & 4 \\
\hline
\end{tabular}

The previous table shows that the name of the tree goddess is appeared in texts ten times while depicted three times with the emblems of Nut and Hathor. Incidentally, her name wasn't mentioned in forty nine times. 
Original or principal identity of the personified tree has attracted more varied opinions. Bissing (1924) pointed out a notable dominance of the goddess Nut in the role of the tree goddess. Incidentally; scholars have through her alleged origin in Old Kingdom tree cults and garden symbolism more often given preference to Hathor (Allam, 1963; Hermsen, 1983; Billing, 2004). Keel (1992) had a discussion that focused on the tree goddess as an iconographical motif.

In addition, Wilkinson (2003) stated that Hathor was sometimes viewed as a sky goddess and Nut sometimes replaces Hathor as the goddess of the divine sycamore tree who nourishes the deceased. PM (1927) mentioned that she was Nut in TT 9, 7, 52, 93, 106, 216, , 299 and western Hathor in TT 255. Ali (2001) relates that she was Nut in TT 4, 5, and 211. Furthermore, Buhl (1947) emphasis that she was Nut in TT 1, 51 while Abdul-Qader (1966) agreed with him and added TT 106, 158.

In brief, to know the name of the goddess, firstly we look to scenes and then texts. The scenes revealed three scenes in which the goddess had her emblems: the first, and the second in TT 50

and 6 she had the emblems of the sky goddess Nut (the $n w$

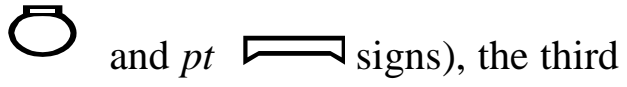
she is represented with the emblem of Hathor (the sun disc between the two horns of a cow) in TT 277.

Although the texts which accompanied the scenes were few but it was an indication for the name of the goddess. They were mentioned Nut and Isis.

Obviously, the scenes and texts were showed that the tree goddess was Nut, Hathor and Isis. Generally, the most texts and scenes attributed to the sky goddess Nut. Accordingly, the features of the three goddesses were the same. In addition, although the scenes and texts refer to the name of the goddess but the most scenes didn't mention any goddess. As a result, the tree goddess was a goddess sometimes takes the features or names of Nut, Isis, and Hathor but it was an independent one.

\section{6- The name of the tree in which the goddess emerge}

From pyramid text and Book of the Dead, the tree was the sycamore and this clear in the scenes but in some scenes it wasn't. TT 63 the text is referring to the sycamore and TT 93 mentioned the sycamore of Nut.

PM (1927) pointed that it was $i \check{s} d$ persa tree in TT 96 while Biki (1993) said the same but in TT 63. As has been noted, the tree was the sycamore and it was obvious from its fruit but sometimes it wasn't clear which the tree is. Indeed, the tree in which the goddess emerged was a tree sometimes was sycamore and others weren't.

\section{Concluding Remarks}

New kingdom Private tombs' scenes reflect the idea of the religious texts about the tree goddess. Indeed, scenes and texts showed that it was connected with Food and water. Scenes from the Book of the Dead which deal with Osiris as a judge in the underworld, and representations of the goddess of the sycamore who feeds the deceased, become very frequent.

The tree goddess was depicted in fifty eight scenes in New Kingdom Theban private tombs. It was shown from the reign of Thutmosis III until the twentieth dynasty.

The goddess appeared as a maid with a tree growing from her head or an integral part of a tree pouring libation and giving offerings of fruits and bread, on a mat whilst the deceased and his wife and sometimes their ba-birds raised their hands to their mouths to enjoy the offerings. Moreover, the deceased is shown alone or with his wife or family under the tree. They were sitting, standing and kneeling in this action. 
The dominance of Nut has been regarded as the result of a process where this alternative mother goddess had merely taken a role that originally belonged to Hathor. The texts and scenes revealed that Nut was the most goddess who represents the tree goddess. Furthermore, the sky goddess was recognized as a conceptual personification, operating around the two basic ideas of space and water as her core attributes. As a result, the tree goddess was a goddess sometimes takes the features or names of Nut, Isis, and Hathor but it was an independent one.

Finally, these scenes were done to insure the water, food, and purification in the afterlife. In addition, the deceased wanted to resemble the god Osiris as shown in chapter 59 of Book of the Dead.

\section{References}

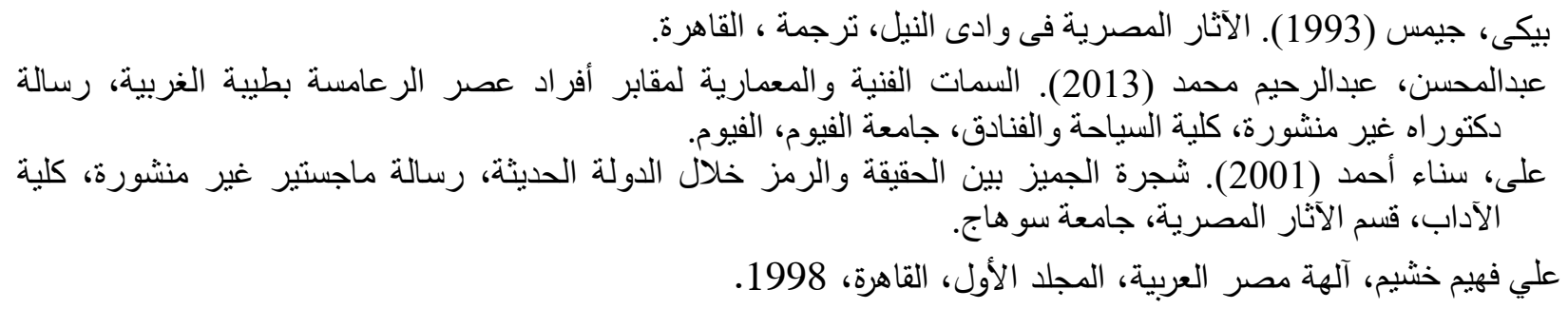

Abd El-Wahab, F., (1959). La Tombe de Sennedjem à Deir el-Medineh. Croquis de Position, MIFAO LXXXX, Le Caire.

Abdel Ghaffar, S., (1994). Das Grab des Sennedjem, Mainz.

Abdul-Qader, M., (1966). The Development of the Funerary Beliefs and Practices Displayed in the Private Tombs of the New Kingdom at Thebes, Cairo.

Allam, S., (1963). Beitrage zum Hathorkult (bis zum Ende des Mittleren Reiches), MAS 4, PP. 103-109.

Assmann, J., (1983). Sonnenhymnen in Thebanischen Gräbern, Theben I, Mainz.

Assmann, J., (1984). "Das Grab mit Gewundenem Abstieg. Zum Typenwandel des PrivatFelsgrabes im Neuen Reich", MDAIK 40, PP. 277-290.

Assmann, J., (1991). Das Grab des Amenemope TT41, Mainz.

Barguet, P., (1967). Le Livre des Morts des Anciens Égyptiens, Paris.

Baud, M., and Driton, E., (1928). Tombes Thébaines, Le Tombeau de Roy (255), Le Caire.

Baud, M., and Driton, E., (1932). Le Tombeau de Panehsy, MIFAO LVII 2, Le Caire.

Billing, N., (2002). "Nut - The Goddess of Life in Text and Iconography", USE 5, PP. 185-192.

Billing, N., (2004). "The Formulation of the Tree Goddess Motif in the Book of the Dead, Ch. 59", SAK 32, PP. 35-50.

Bissing, V. (1924). "Munchener Jahrbuch der bildenden Kunst", Neue Folge 1, PP. 211-212.

Bleeker, C., (1973). Hathor and Thoth: Two Key Figures of the Ancient Egyptian Religion, Vol. 26, Brill.

Bruyėre, B., (1928). Rapport sur Les Fouilles de Deir El Médineh (1927), FIFAO 5, Le Caire.

Budge, E., (1910).The Book of the Dead, London.

Buhl, M., (1947). "The Goddesses of the Egyptian Tree Cult", JNES 6, No. 2, PP. 80-97.

Calmettes, M., (2007). "La tombe de Sennefer, Réflexions sur le Programme Décoratif du Caveau (TT 96B)", Revue Égypte, Afrique \& Orient $N^{\circ} 45$, PP.53-64.

Cumming, B., (1984). Egyptian Historical Records- Fascicle II, England.

Davies, N., (1900). The Mastaba of Ptahhetep and Akhethetep at Saqqareh. Part I: The Chapel of Ptahhetep and the Hieroglyphs, Cairo. 
Davies, N., (1917). The Tomb of Nakht at Thebes, Vol. I, New York.

Davies, N., (1917). The Tomb of Puyemre at Thebes, Vol. II, New York.

Davies, N., (1927). Two Ramesside Tombs at Thebes, New York.

Davies, N., (1933). The Tomb of Neferhotep at Thebes, Vol. 1, New York.

Davies, N., (1973). The Tomb of Kenamun at Thebes, Vol. 1, New York.

Davies, N., and Gardiner, A., (1948). Seven Private Tombs at Qurnah, London.

Eggebrecht, A., (1986). "Sen-nefer ", Die Grabkammer Des Burgermeisters Von Theben, Philipp Mainz.

El-Shahawy, A., (2010). "Recherche sur la Décoration des Tombes Thébaines du Nouvel Empire. Originalités iconographiques et Innovations", IBAES XIII, PP. 151-162.

Eschweiler, B., (1994). Bildzauber im alten Agypten. Die Verwendung von Bildern und Gegenstanden in magischen Handlungen nach den Texten des Mittleren und Neuen Reiches, OBO 137, Berlin.

Faulkner, R., (1969). The Ancient Egyptian Pyramid Texts. Oxford.

Faulkner, R., (1978). The Ancient Egyptian Coffin Texts, Vol. III, Oxford.

Faulkner, R., (1977). The Ancient Egyptian Coffin Texts, Vol. III, Oxford.

Foucart, G., (1918). "Sur Quelques Représentations des Tombes Thébaines", BIE 5, PP. 63-73.

Foucart, G., (1924). " Les Précurseurs du Soleil", BIFAO 24, PP. 71- 96.

Foucart, G., (1932). Tombes Thébaines Necropole de Dira Abu Naga, Le Tombbeau d' Amonmos, MIFAO 57, Le Caire.

Germer, R., (2001). "Flora", The Oxford Encyclopedia of Ancient Egypt, Vol. I, PP. 535- 541.

Ghaly, E., (2017). The Scenes of the Private Tombs of the Post-Amarna Period at Thebes and Memphis, A comparative Study, unpublished PhD, Faculty og Tourism and Hotels, Fayoum University, Fayoum.

Hari, R., (1985). La Tombe Thèbaine du Père Neferhotep (TT 50), Genève.

Haring, B., (2007). The Tomb of Sennedjem (TT1) in Deir El-Medina, Paleography, Cairo.

Hart, G., (1986). A Dictionnary of Egyptian Gods and Goddesses, London.

Taylor, J., (2010). Ancient Egyptian Book of the Dead, London.

Hartwig, M., (2004). Tomb Painting and Identity in Ancient Thebes, 1419-1372 BC, Brussels.

Helck, W., (1956). Urkunden der 18, Dynastie, Berlin.

Hermsen, E., (1981). Lebenbaumsymbolik im alten Ägypten, London.

Hofmann, E., (2004). Bilder im Wandel. Die Kunst der Ramessidischen Privatgräber, Theben XVII, Mainz.

Hornung, E. (1990). Das Totenbuch der Ägypter, München.

Jourdain, G., (1939). La Tombe du Scribe Royal Amenemopet, MIFAO 73/2, Le Caire.

Kammp, F., (1996). Die Thebanische Nekropole, zum Wandel des Grabgedankens, von der XVIII. bis zur XX. Dynastie, Theben XIII, Mainz.

Keel, O. (1992). Das Recht der Bilder gesehen zu werden. Drei Fallstudien zur Methode der Interpretation altorientalischer Bilder, OBO 122, Berlin.

Maspero, G., (1910). The Dawn of Civilization, London.

Murray, M., (2000). "Fruits, Vegetables, Pulses and Condiments: Onion", Ancient Egyptian Materials and Technology, Cambridge, PP. 620-640.

Polz, D., (1997). Das Grab des Hui und des Kel, Theben Nr. 54, Mainz.

Porter, B., and Moss, R., (1927). Topographical Bibliography of Ancient Egyptian Hieroglyphic, Texts, Reliefs and Paintings, Vol. 1, Oxford. 
International Journal of Heritage, Tourism and Hospitality Vol. (11), No. (3/2)

Special issue on papers of the $10^{\text {th }}$ ICTH (2017) organized by Faculty of Tourism and Hotels, Fayoum University

Quirke, S., (2013). Going Out in Daylight prt $m$ hrw, The Ancient Egyptian Book of the Dead, Translations, Sources and Meaning, London.

Robins, G., (1994). Proportion and Style in Ancient Egypt Art, London.

Saleh, M., (1948). Das Totenbuch in den Thebanischen Beamtengräbern des Neuen Reiches, Kairo.

Seele, K., (1959).The Tomb of Tjanefer at Thebes, OIP 86, Chicago.

Shedid, A., (1994). Das Grab des Sennedjem, Mainz.

Shedid, A., and Seidel, M., (1996). The Tomb of Nakht. The Art and History of an Eighteenth Dynasty Official's Tomb at Western Thebes, Mainz.

Speigel, J. (1956). "Die Entwicklung der Opferszenen den Thebanischen Grabren", MDAIK 14, Kairo, PP. 190- 207

Tirand, H., (1910). The Book of the Dead, London.

Vandersleyen, C., (2012). Histoire de l'Art Egyptien, Safran.

Vandier d'Abbadie, J., (1954). Deux Tombes Ramessides à Gournet-Mourrä̈, MIFAO 87, Le Cairo.

Virey, Ph., (1898). "La Tombe des Vignes à Thebes", Recueil de Travaux XX, PP. 217- 219.

Weeks, K., (2005). The Illustrated Guide to Luxor, Cairo.

Wild, H., (1979). La Tombe de Néferhotep (I) et Nebnéfer à Deir el-Médîna (No. 6) et Autres Documents les Concernant, MIFAO 103, II, Le Caire.

Wildung, D., (1978). Agyptische Malerei, Das Grab des Nacht, Munich.

Wildung, D., (1978). Agyptische Malerei, Das Grab des Nacht, Munich.

Wilkinson, J., (1874). The Manner and Custom of the Ancient Egyptians, Vol. III, London.

Wilkinson, R., (1992). Reading Egyptian Art, London.

Valbelle, D., (1985). Les Ouvriers de la Tombe. Deir el-Medineh à l'Epoque Ramesside, IFAO,

Le Caire.

Virey, Ph., (1898). "La Tombe des Vignes à Thebes", Recueil de Travaux, Vol. XX, PP. 217219.

Wilkinson, R., (2003). The Complete Gods and Goddesses of Ancient Egypt, London.

Wreszinski, W., (1923). Atlas Zur Alta EgyptIischan Kultureschichte, Leipzig.

\section{Figures}

Figure 1: Scene from Book of the Dead, Ch. 59 (Hornung, E., 1990; Abb. 31; Keel. O., 1992, Abb. 32a).
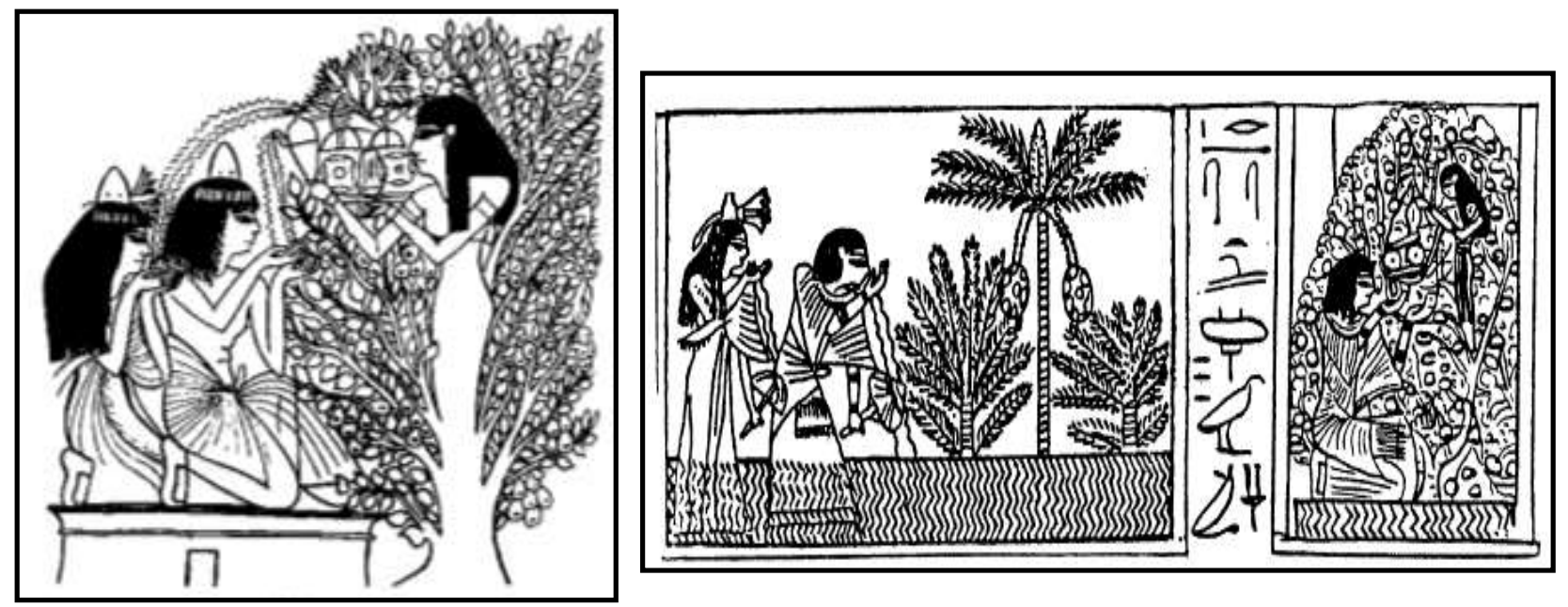
International Journal of Heritage, Tourism and Hospitality Vol. (11), No. (3/2)

Special issue on papers of the $10^{\text {th }}$ ICTH (2017) organized by Faculty of Tourism and Hotels, Fayoum University

Figure 2: Scene from Book of the Dead, Ch. 63A (Hornung, E., 1990, Abb. 34).

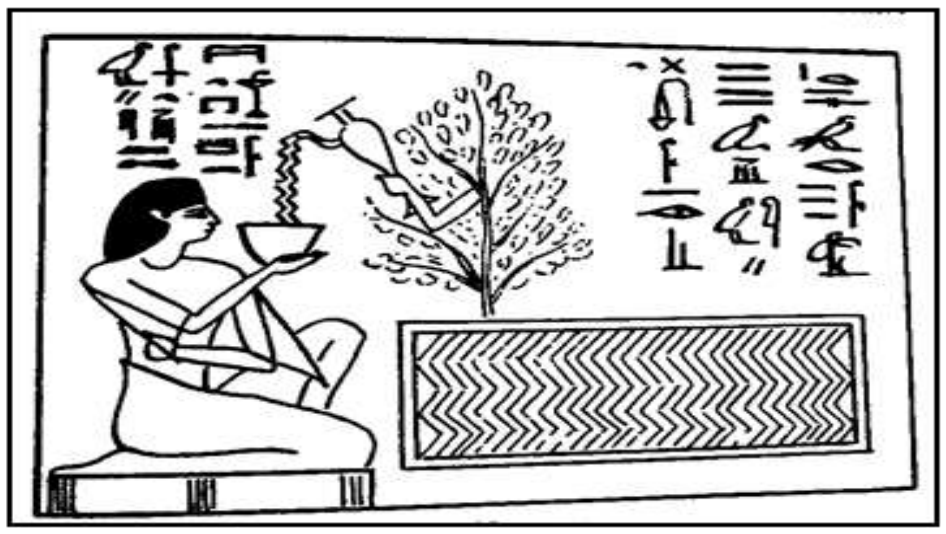

Figure 3: Tomb of Puyemre (TT 39) at El-Khokha (Davies, N. ,1922, PL. 56).

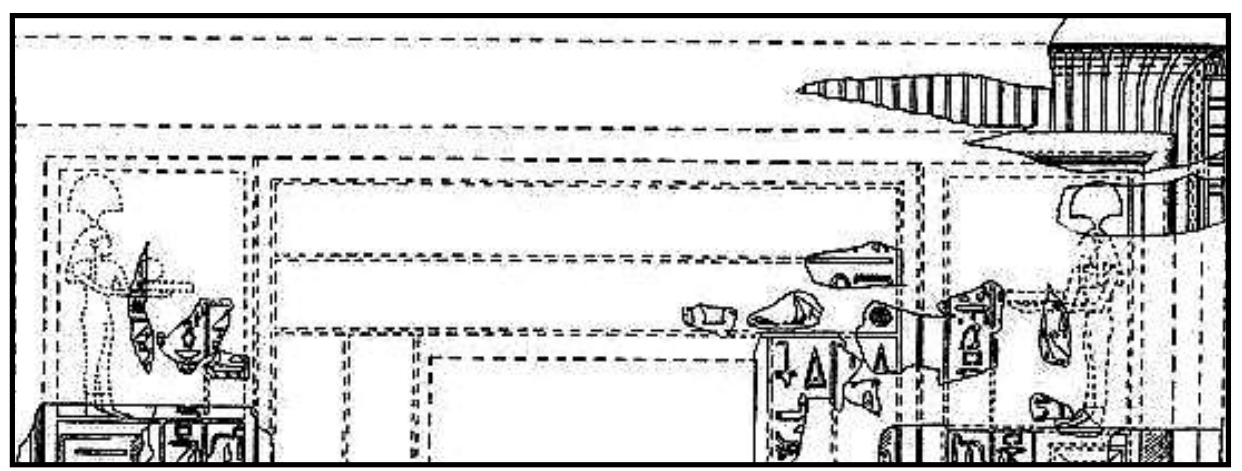

Figure 4: Tomb of Kenamun (TT 93) at Shaikh Abd El-Qurna (Davies, N., 1922, PL. 66).

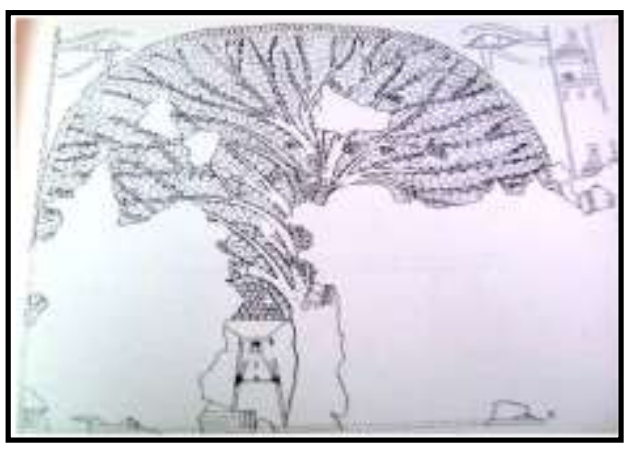

Figure 5: Tomb of Sennufer (TT 96 B) at Shaikh Abd ElQurna ( Abd El-Mohsen, A., 2013, Fig. 375).

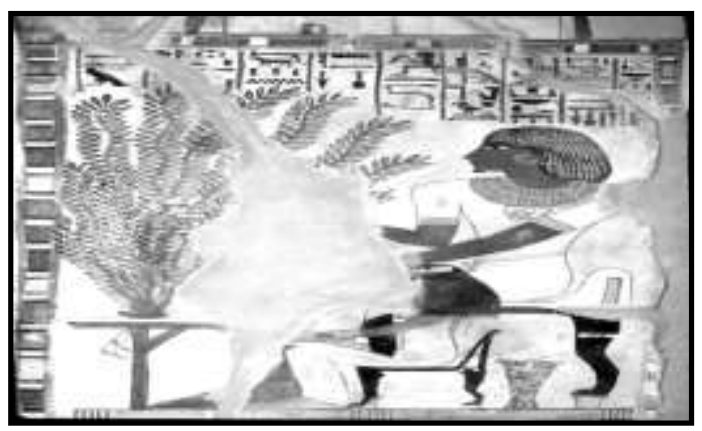

Figure 6: Tomb of Nakht (TT 52) at Shaikh Abd El-Qurna (Davies, N., 1917, PL.

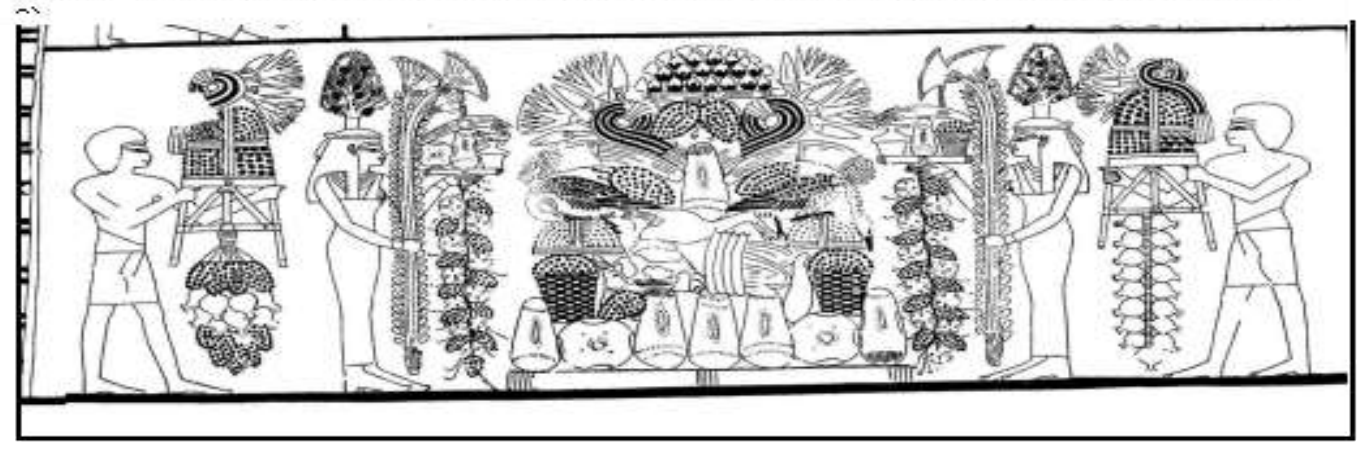


International Journal of Heritage, Tourism and Hospitality Vol. (11), No. (3/2)

Special issue on papers of the $10^{\text {th }}$ ICTH (2017) organized by Faculty of Tourism and Hotels, Fayoum University

Figure 7: Tomb of Sobekhotep (TT63) at Shaikh Abd El-Qurna (Abdul-Qader, M., 1966, PL. 51).

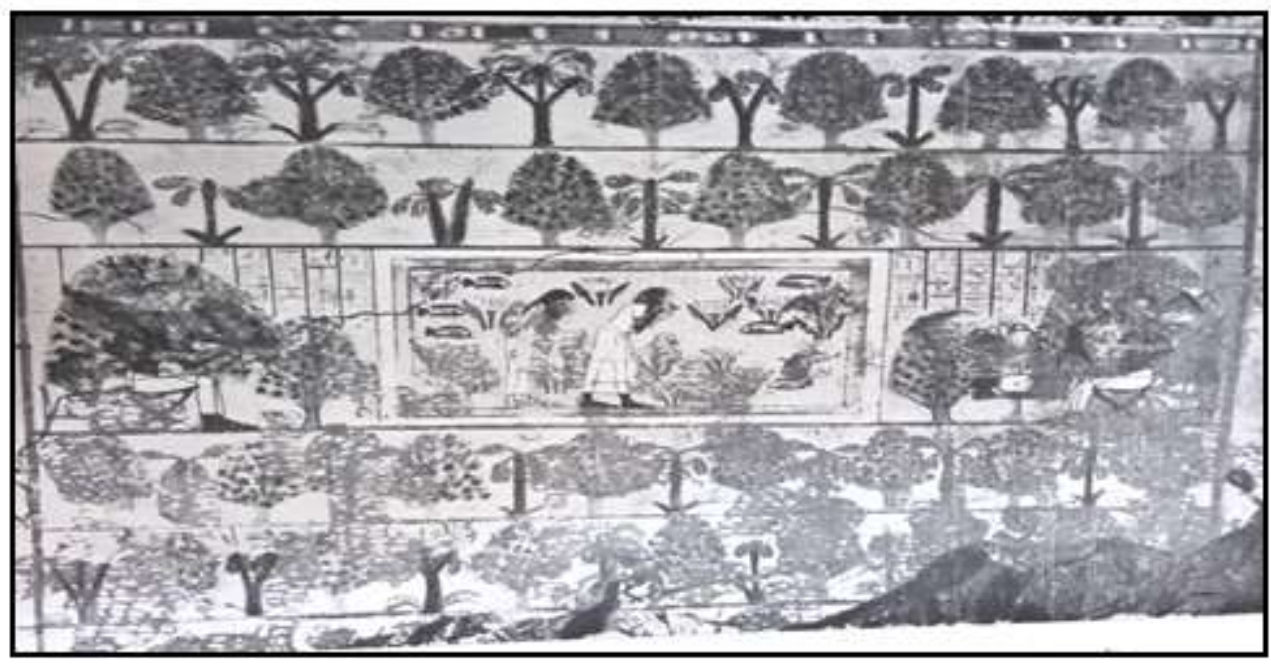

Figure 8: Tomb of Nefehotep (TT 49) at El-Khokha (Davies, N. 1933. PL. 40).

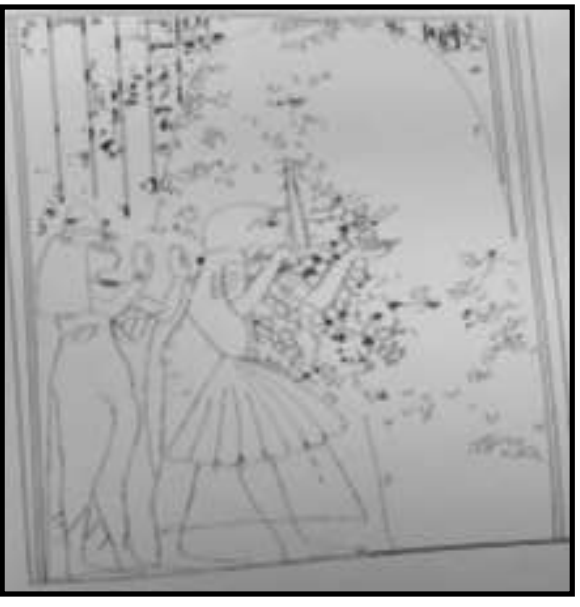

Figure 9: Tomb of Neferhotep tomb (TT 50) at Shaikh Abd ElQurna (Hari, R. 1985, PL. 26).

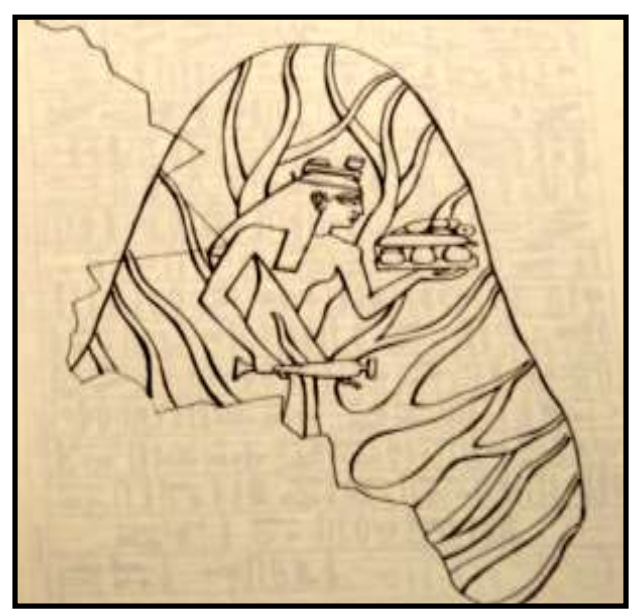

Figure 10: Tomb of Roy (TT 255) at Dra Abu El-Naga (Baud, M., and Driton, E., 1928. Fig. 13).

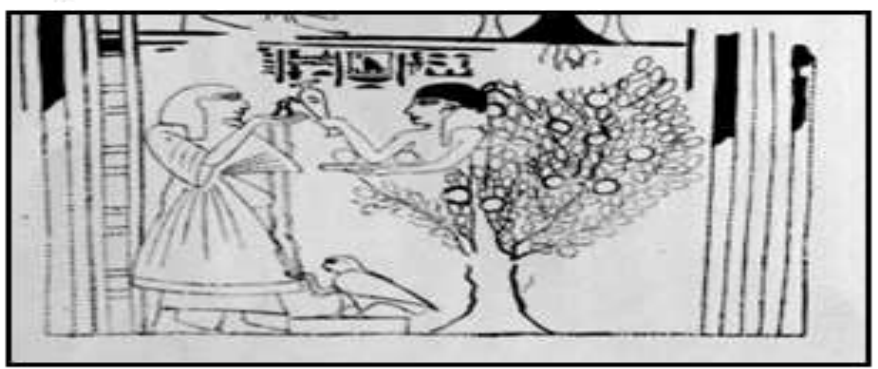


International Journal of Heritage, Tourism and Hospitality Vol. (11), No. (3/2)

Special issue on papers of the $10^{\text {th }}$ ICTH (2017) organized by Faculty of Tourism and Hotels, Fayoum University

Figure 11: Tomb of Amunmose (TT 19) at Dra Abu El-Naga (Foucart, G., 1932, PL.

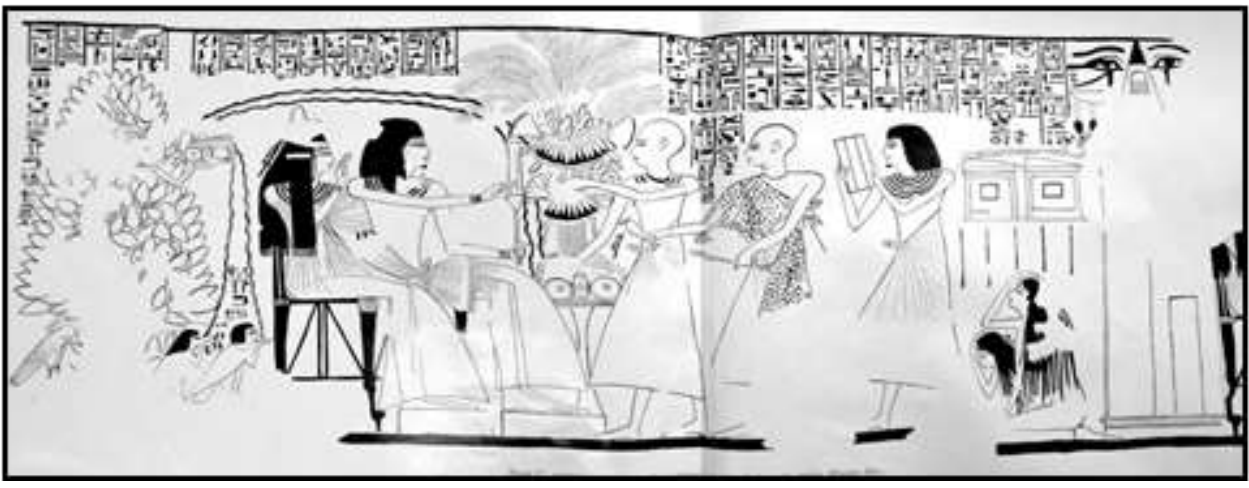

Figure 12: Tomb of Amenemope (TT 41) at Shaikh Abd E1-Qurna (Assmann, J., 1991, Taf: 40).

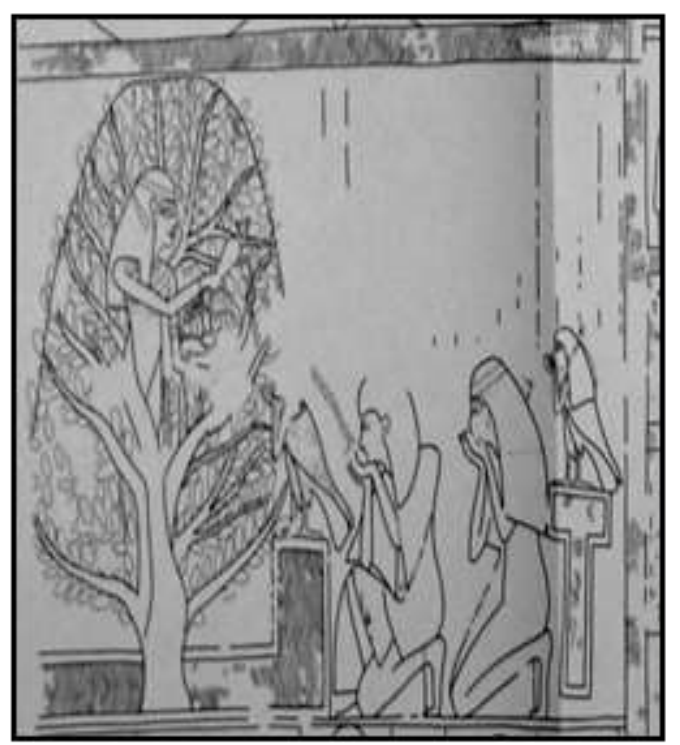

Figure 13: Tomb of Userhet (TT 51) at Shaikh Abd El-Qurna (Davies, N.,

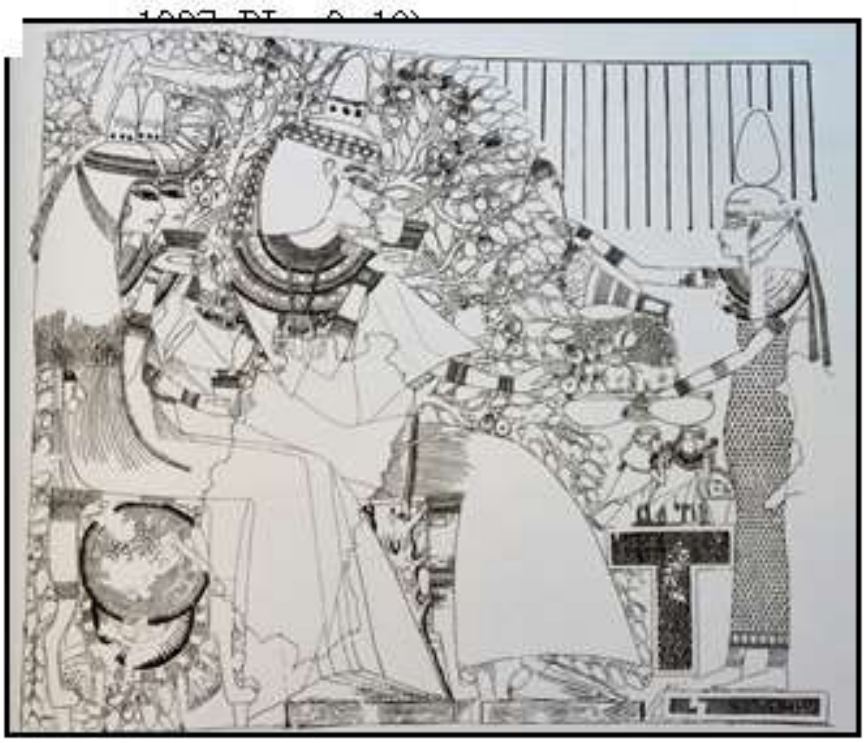

Figure 14: Tomb of Neferhotep (TT 6) at at Deir el-Medina (Foucart, G.,

Figure 15: Tomb of Panehsy (TT 16) at Dra Abu E1Waorarsaleh M 1084 Fio $3 \mathrm{~m}$
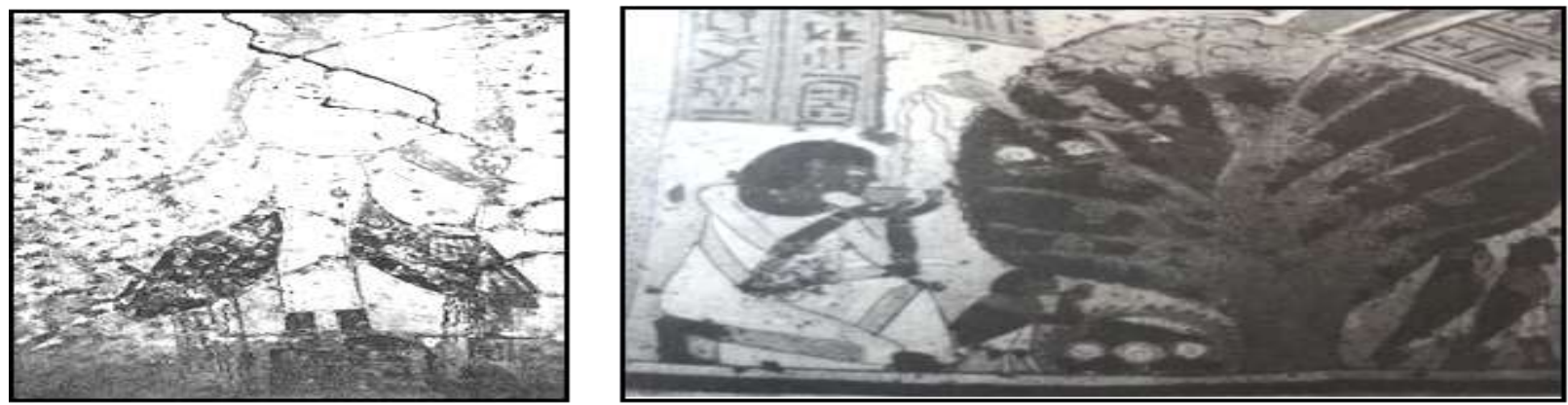
International Journal of Heritage, Tourism and Hospitality Vol. (11), No. (3/2)

Special issue on papers of the $10^{\text {th }}$ ICTH (2017) organized by Faculty of Tourism and Hotels, Fayoum University

Figure 16: Tomb of Tianufer (TT 158) at Dra Abu El-Naga (Abdul-Qader, M., 1966, PL. 51).

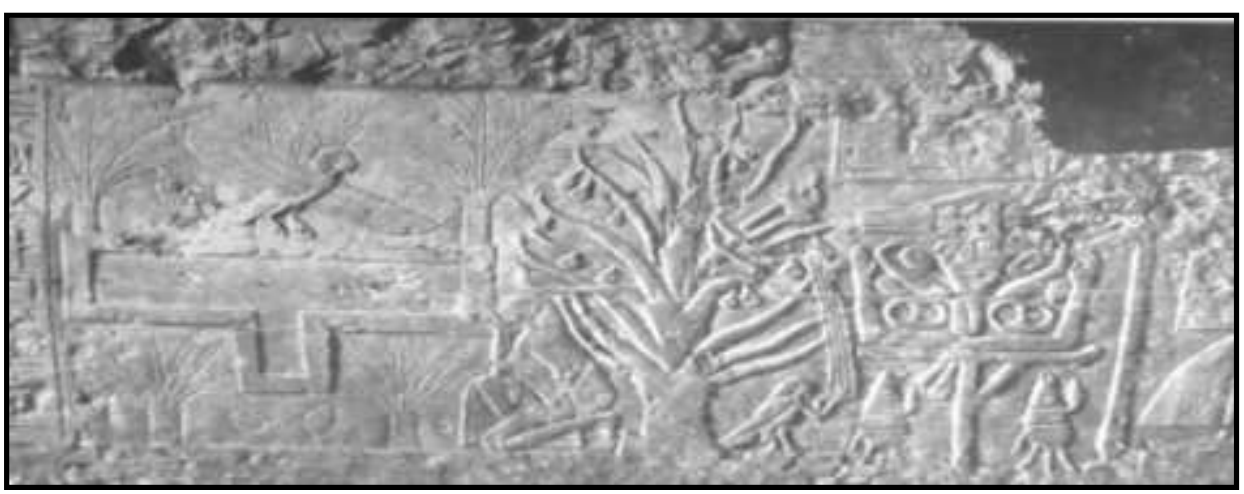

Figure 17: Tomb of Amunnakht (TT 341) at Shaikh AbdE1-Quma (Davies, N., 1928. PL. 29).

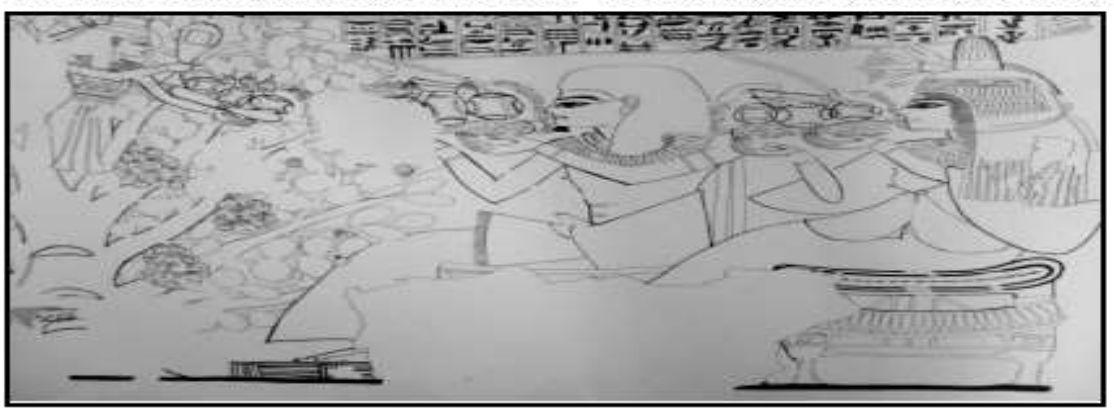

Figure 18: Tomb of Sennedjem (TT 1) at Deir E1-Medina (AbdE1-Mohsen, A., 2013, Fig. 385).

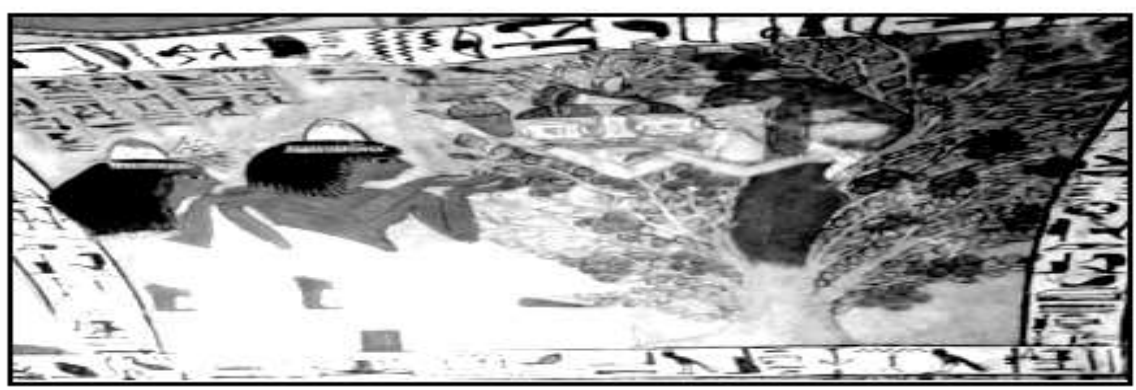

Figure 19: Tomb of Hui (TT 54) at Shaikh Abd E1-Qurna (Polz, D., 1997, T af. 21).

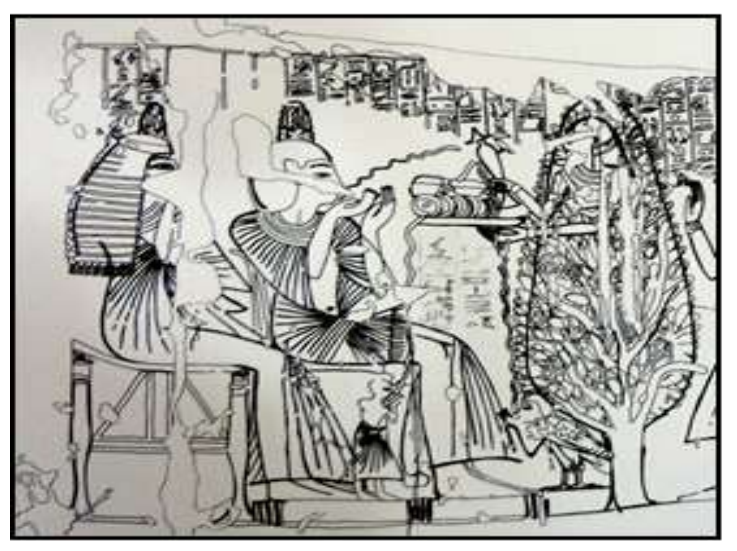

Figure 20: Tomb of Inherkau (TT 299) at E1Khokha (Buyyere, B., 1928, Fig. 22).

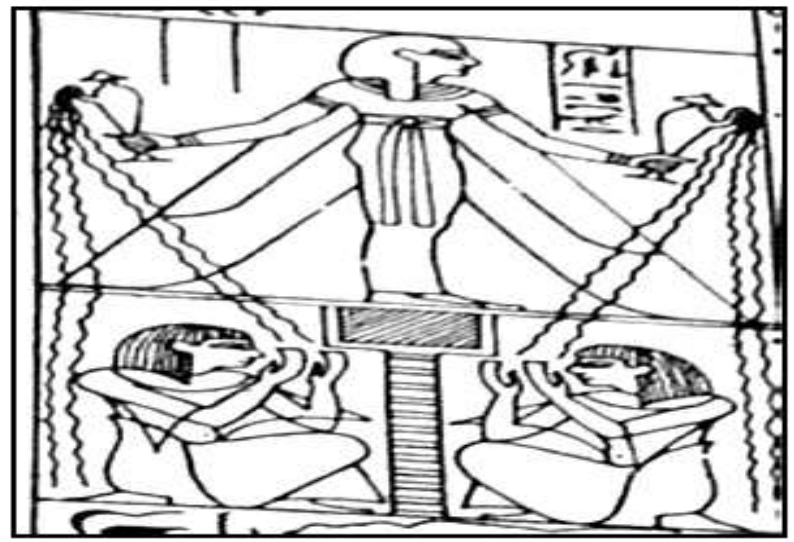

119 
Figure 21: Tomb of Amunemounet (TT 277) at Qurnet Murai (Vandier d'Abbadie, J., 1954, PL. 32).

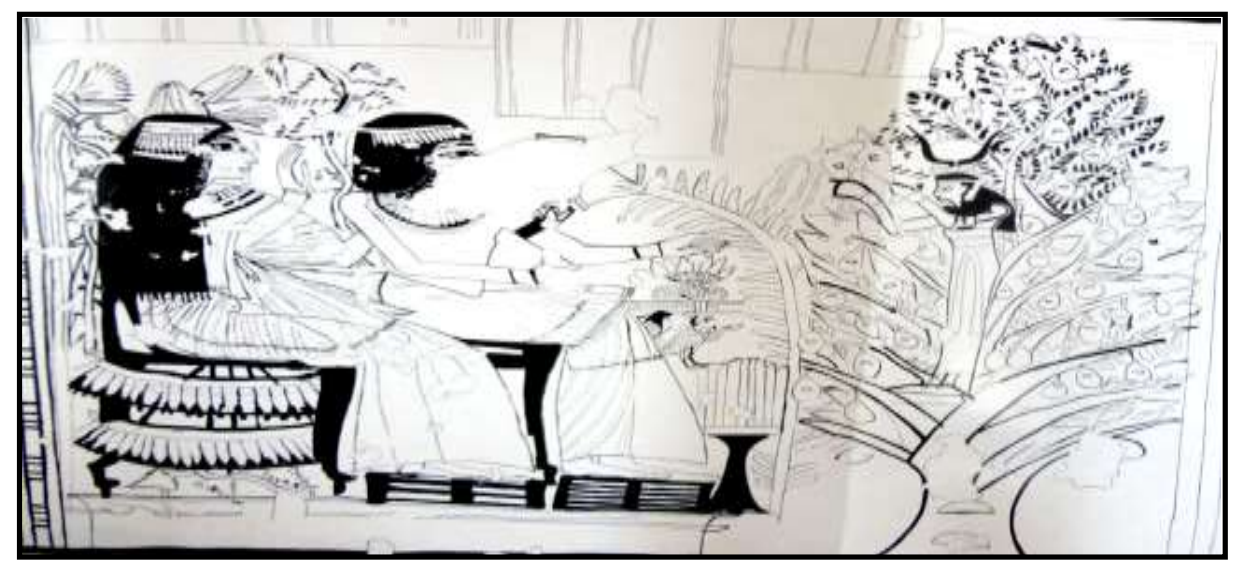

Figure 22: Tomb of Haty'ay (TT 324) at Shaikh Abd El-Qurna (Davies, N., 1948, PL. 34).

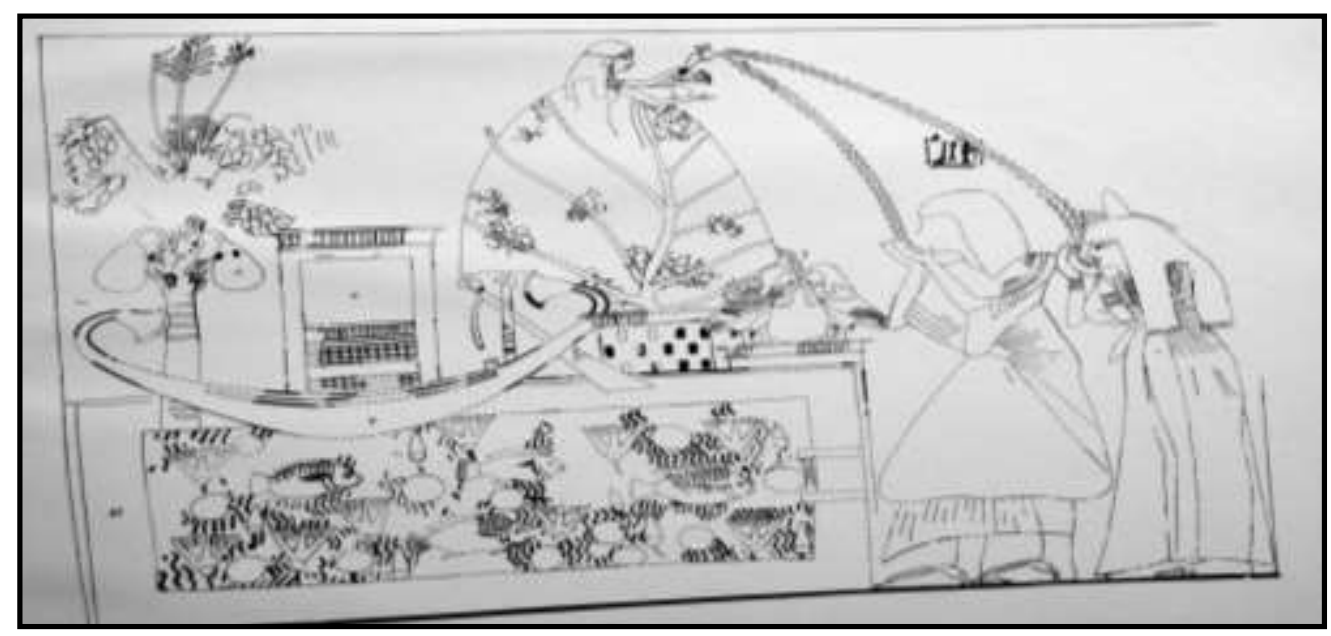

